Economics Development Analysis Journal

\title{
Efektivitas Kebijakan Angkutan Umum Berbadan Hukum pada Angkutan Antar Kota dalam Provinsi
}

\section{Windy Kartika Dewi ${ }^{\bowtie}$}

Jurusan Ekonomi Pembangunan, Fakultas Ekonomi, Universitas Negeri Semarang

\begin{tabular}{|c|c|}
\hline Info Artikel & Abstrak \\
\hline $\begin{array}{l}\text { Sejarah Artikel: } \\
\text { Diterima Juli } 2018 \\
\text { Disetujui September } 2018 \\
\text { Dipublikasikan November } \\
2018\end{array}$ & $\begin{array}{l}\text { Kebijakan angkutan umum berbadan hukum mengenai kewajiban angkutan umum berbadan } \\
\text { hukum menuai berbagai pendapat dari pengusaha angkutan umum di Jawa Tengah. Hingga } \\
\text { akhir bulan Juli } 2017 \text { mayoritas kepemilikan AKDP (Angkutan Umum Antar Kota Dalam } \\
\text { Provinsi) di Jawa Tengah masih bersifat perorangan atau belum berbadan hukum dan hanya } \\
\text { sebesar } 57 \text { persen yang sudah berbadan hukum. Jenis penelitian ini adalah deskriptif kualitatif } \\
\text { dengan analisis deskriptif persentase dan analisis interactive model untuk mengetahui } \\
\text { efektivitas kebijakan angkutan umum berbadan hukum serta faktor pendorong dan faktor } \\
\text { penghambat pelaksanaan kebijakan angkutan umum berbadan hukum pada AKDP di beberapa } \\
\text { kabupaten di Jawa Tengah. Hasil penelitian ini menunjukkan bahwa efektivitas kebijakan } \\
\text { angkutan umum berbadan hukum pada AKDP di Jawa Tengah belum tercapai. Adapun } \\
\text { kendala yang dihadapi yaitu tidak diterapkannya sanksi dari pemerintah kepada angkutan } \\
\text { umum yang belum berbadan hukum dan akibat terbitnya Peraturan Menteri Dalam Negeri } \\
\text { Nomor } 28 \text { Tahun } 2017 \text { mengenai pengurangan subsidi yang diterima pengusaha angkutan } \\
\text { umum yang sudah berbadan hukum. }\end{array}$ \\
\hline
\end{tabular}

\section{Abstract}

The incorporated public transport policieson the obligation of public transports receive various opinions from the public transportowners in Central Java.In the last of July 2017, the majority of buses in Central Java were still owned individually or have not legal entities yet. There were 57 percent of incorporated public transport in Central Java. This study is a descriptive qualitative study by using descriptive percentage analysis and interactive model analysis to know the effectiveness of the incorporated public transport policies and to find out the contributing factors to the effectiveness of the implementation of the incorporated public transport policies on buses in some districts in Central Java. The result of the investigation showed that the effectiveness of the incorporated public transport policies have not achieved yet. There are two obstacles faced in implementing the incorporated public relation policies: (1) No punishment from the government to the public transports which have not legal entities yet; (2) The impact of Permendagri No $28 / 2017$ on the subsidy reduction received by the owners of incorporated public transports.

(C) 2018, Universitas Negeri Semarang

\footnotetext{
Alamat Korespondensi :

Gedung L2 Lantai 2 FE Unnes

Kampus Sekaran, Gunungpati, Semarang, 50229

E-mail: edaj@mail.unnes.ac.id
}

ISSN 2252-6965 


\section{PENDAHULUAN}

Pengenaan kebijakan angkutan umum berbadan hukum terkait pemberian subsidi pajak untuk angkutan umum berbadan hukum sudah berlaku pada saat kenaikan BBM (Bahan Bakar Minyak) guna meringankan beban pengusaha angkutan umum. Tujuan utama pemerintah memberlakukan kewajiban angkutan umum berbadan hukum yaitu agar pengusaha angkutan umum dapat memanfaatkan pemberian insentif pajak dari pemerintah, memudahkan pemerintah melakukan pengawasan penyelenggaraan angkutan umum, memperlancar koordinasi, serta ketertiban angkutan umum lebih terstruktur dalam pengendalian. Jadi pemerintah lebih mudah dalam mengawasi kelayakan transportasi angkutan umum (Tangselpos.co.id).

Berdasarkan Peraturan Menteri Dalam Negeri Nomor 101 Tahun 2014 menjelaskan bahwa kendaraan bermotor angkutan umum orang dan kendaraan bermotor angkutan umum barang wajib berbadan hukum Indonesia dengan ketentuan peraturan perundangundangan paling lama 1 (satu) tahun sejak Peraturan Menteri diundangkan. Mengacu pada Peraturan Menteri Dalam Negeri Nomor 101 Tahun 2014 mengenai pemberlakuan subsidi bagi kendaraan angkutan umum orang dan angkutan umum barang yang berbadan hukum, peraturan tersebut dijabarkan oleh Pemerintah Provinsi Jawa Tengah dengan diterbitkannya Peraturan Gubernur Jawa Tengah Nomor 23 Tahun 2015 tentang Penghitungan Dasar Pengenaan Pajak Kendaraan Bermotor dan Bea Balik Nama Kendaraan Bermotor Untuk Kendaraan Bermotor Pembuatan Sebelum Tahun 2015 yang menjelaskan bahwa kendaraan bermotor angkutan umum orang dan angkutan umum barang yang dimiliki secara perorangan wajib diubah menjadi badan hukum Indonesia paling lambat tanggal 31 Desember 2015. Dasar penetapan PKB (Pajak Kendaraan Bermotor) dan BBNKB (Bea Balik Nama Kendaraan Bermotor) untuk angkutan umum orang dan angkutan umum barang yang belum berbadan hukum setelah tanggal 31 Desember 2015 ditetapkan sebagai kendaraan pribadi.

Pelaksanaan suatu kebijakan tidak akan terlepas dari berbagai macam kendala dalam mencapai tujuannya. Berbagai kendala tersebut akan muncul dengan berjalannya pelaksanaan kebijakan tersebut. Dalam pelaksanaan di lapangan dengan diberlakukannya regulasi berupa kewajiban angkutan umum berbadan hukum dalam praktiknya dinilai memiliki kendala yang menyebabkan mayoritas kepemilikan angkutan umum di Jawa Tengah bersifat perorangan atau belum berbadan hukum. Gambar 1 menunjukkan bahwa Jumlah AKDP (Angkutan Umum Antar Kota Dalam Provinsi) di Jawa Tengah yang berbadan hukum mengalami peningkatan pada tiap tahunnya. Dengan adanya kebijakan angkutan umum berbadan hukum, berdasarkan Peraturan Gubernur Jawa Tengah Nomor 23 Tahun 2015 yang menjelaskan bahwa angkutan umum orang dan angkutan umum barang yang dimiliki perorangan wajib diubah menjadi badan hukum paling lambat tanggal 31 Desember 2015. Kenyataannya hingga akhir tahun 2016 jumlah AKDP di Jawa Tengah yang berbadan hukum lebih sedikit dibandingkan dengan jumlah AKDP yang masih dimiliki perorangan yaitu berjumlah 2758 AKDP yang sudah berbadan hukum.

Berdasarkan permasalahan di atas dapat diketahui bahwa perlu adanya pengawasan serta sosialisasi kepada pengusaha angkutan umum di Jawa Tengah dalam rangka pelaksanaan kebijakan angkutan umum berbadan hukum dari sisi teknis pelaksanaan, ketentuan, dan aturan yang jelas. Sehubungan dengan permasalahan yang diuraikan di atas untuk mengetahui pelaksanaan serta faktor pendorong dan faktor penghambat dalam pelaksanaan kebijakan angkutan umum berbadan hukum pada AKDP di beberapa kabupaten di Jawa Tengah, maka mendorong penulis untuk meneliti lebih lanjut tentang Efektivitas Kebijakan Angkutan Umum Berbadan Hukum pada AKDP di Beberapa Kabupaten di Jawa Tengah. 


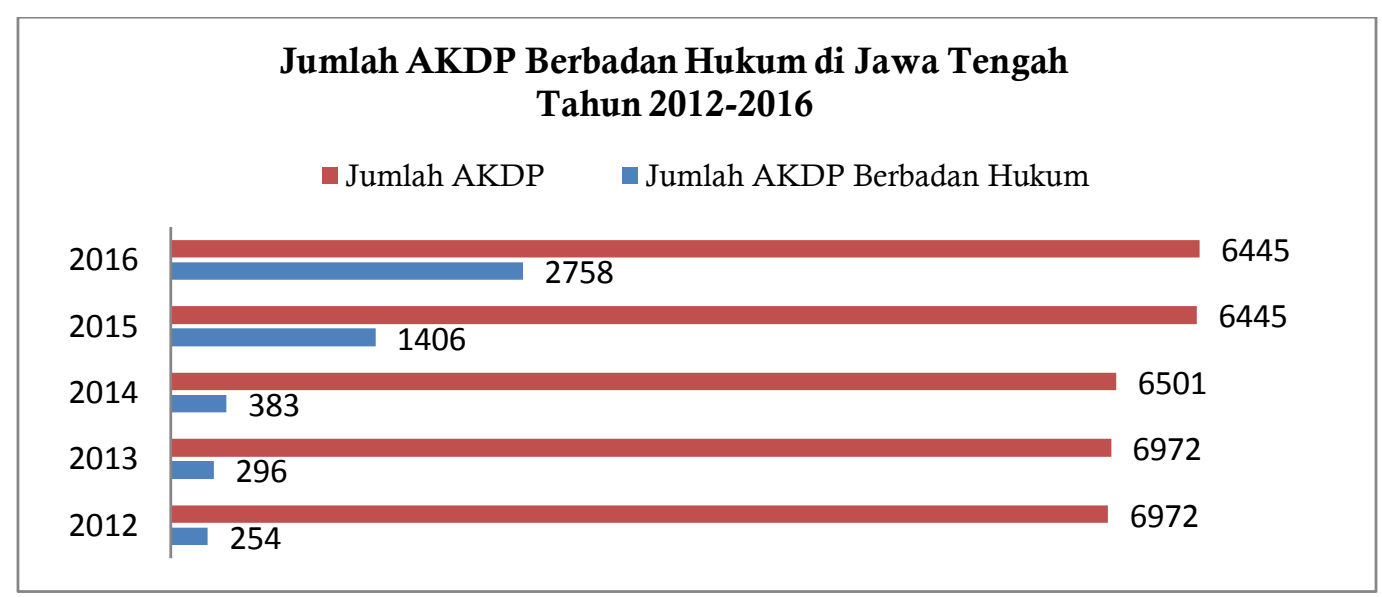

Gambar 1. Jumlah AKDP Berbadan Hukum di Jawa Tengah Tahun 2012-2016 Sumber: Dinas Perhubungan Provinsi Jawa Tengah, 2017

\section{METODE PENELITIAN}

Jenis data yang digunakan dalam penelitian ini adalah data primer dan sekunder. Data primer yang diperoleh dari penelitian ini yaitu wawancara, observasi, dan dokumentasi kepada Dinas Perhubungan Provinsi Jawa Tengan, DPD Organda Provinsi Jawa Tengah, dan pengusaha AKDPdi Karanganyar, Kendal, Grobogan, Kudus, dan Jepara. Adapun kriterianya adalah: Kabupaten/kota dengan jumlah kendaraan AKDP yang sudah berbadan hukum rendah dibandingkan dengan kabupaten/kota yang lainnya, Kabupaten/kota yang memiliki jumlah koperasi dan PT yang bergerak di bidang usaha angkutan umum minimal 3 (tiga) dalam daerah tersebut, Kabupaten/kota yang mempunyai koperasi dan PT yang bergerak di bidang usaha angkutan umum di dalam daerah tersebut.

Data sekunder diperoleh dari Dinas Perhubungan Provinsi Jawa Tengah yaitu data jumlah AKDP berbadan hukum di Jawa Tengah dan Jumlah PT dan koperasi yang bergerak di bidang usaha angkutan umum di Jawa Tengah.

Penelitian ini menggunakan metode analisis deskriptif persentase dan analisis interactive model oleh Miles dan Huberman. Deskriptif persentase digunakan untuk mengetahui keberhasilan program dengan mengetahui keefektifan kebijakan angkutan umum berbadan hukum pada AKDP di Jawa Tengah.

EfektivitasProgram $=\frac{\text { Realisasi }}{\text { Target }} \times 100 \% \ldots .(1)$

Keterangan:

Realisasi = Jumlah program yang telah dilaksanakan

Target = Seluruh tujuan program kebijakan angkutan umum berbadan hukum pada AKDP di Jawa Tengah

Selanjutnya dilakukan pengklasifikasian tingkat efektivitas sesuai dengan klasifikasi criteria nilai efektivitas. Berdasarkan Keputusan Menteri Dalam Negeri Nomor 690.900-327 Tahun 1996 klasifikasi kriteria nilai efektivitas seperti terlihat pada tabel berikut ini :

Tabel 1. Rasio Efektivitas

\begin{tabular}{cl}
\hline Persentase $(\%)$ & \multicolumn{1}{c}{ Kriteria } \\
\hline$>100$ & Sangat Efektif \\
$90-100$ & Efektif \\
$80-90$ & Cukup Efektif \\
$60-80$ & Kurang Efektif \\
$<60$ & Tidak Efektif \\
\hline Sumber : Tim Litbang Depdagri - Kemendagri
\end{tabular}


Analisis Interactive Model menurut Miles dan Huberman (1984)dalam Sugiyono (2016) yaitupengumpulan data, reduksi data, penyajian data, dankesimpulan/verifikasi. Adapun langkah-langkahnya sebagai berikut:

Dalam penelitian ini pengumpulan data dilakukan dengan tiga teknik yaitu wawancara, observasi, dan dokumentasi. Reduksi data dalam penelitian ini dilakukan setelah mendapatkan hasil wawancara terkait dengan efektivitas kebijakan angkutan umum berbadan hukum pada AKDP di beberapa kabupaten di Jawa Tengah. Hasil wawancara yang sudah dilakukan kemudian dipilah sesuai fungsi reduksi data sehingga data yang dihasilkan dapat diinterprestasikan dengan baik.

Peneliti menyajikan data dalam penelitian ini dengan menggunakan uraian singkat yang dideskripsikan oleh peneliti dalam bentuk naratif dan menyajikan data dalam bentuk tabel sehingga memudahkan peneliti dalam menganalisis data yang diperoleh.

Penarikan kesimpulan dalam penelitian ini dilakukan dengan membuat rumusan yang akan ditanyakan, mengangkat hasil yangtelah dilakukan sebagai temuan, mengkaji secara berulang-ulang terhadap data yang ada, pengelompokan data yang telah terbentuk, dan setelah data dan informasi tersebut sesuai kemudian dapat ditarik kesimpulan dari setiap item yang ada.

Teknik penentuan informan menggunakan teknik purposive sampling dan didasarkan pada ketentuan atau kejenuhan data dan informasi yang diberikan.

\section{HASIL DAN PEMBAHASAN}

Masih banyak kepemilikan AKDPdi Jawa Tengah yang dimiliki perseorangan atau belum berbadan hukum. Tercatat pada akhir tahun 2016 jumlah AKDP yang berbadan hukum adalah 2758 kendaraan. Berdasarkan data yang diperoleh dari Dinas Perhubungan Provinsi Jawa Tengah pada akhir bulan Juli 2017 jumlah AKDP berbadan hukum meningkat yaitu berjumlah 3690 kendaraan AKDP yang berbadan hukum. Namun dengan bertambahnya jumlah AKDP berbadan hukum tersebut belum dapat dikatakan bahwa dalam pelaksanaan kebijakan angkutan umum berbadan hukum pada AKDP di beberapa kabupaten di Jawa Tengah sudah berjalan sesuai dengan target yang ditetapkan oleh pemerintah. Hal tersebut dikarenakan belum seluruhnya angkutan umum di Jawa Tengah berbadan hukum.

Pengukuran efektivitas suatu program kebijakan angkutan umum berbadan hukum pada AKDP di beberapa kabupaten di Jawa Tengah dilakukan dengan menggunakan 4 (empat) pendekatan oleh Budiandi (2007) yaitu ketepatan sasaran program, sosialisasi program, tujuan program, dan pemantauan program dapat dijelaskan sebagai berikut :

Kemampuan suatu daerah dalam menjalankan program kebijakan ataupun tugas yang telah ditetapkan sebelumnya dikategorikan efektif apabila rasio pencapaian dari hasil pelaksanaan kebijakan tersebut minimal sebesar 100\%.(Suseno, 2013).

Pelaksanaan kebijakan angkutan umum berbadan hukum pada AKDP di Karanganyar, Kendal, Grobogan, Kudus, dan Jepara menunjukkan bahwa mayoritas kepemilikan angkutan umum masih bersifat perorangan atau belum berbadan hukum. Angkutan umum jenis AKDP yang belum berbadan hukum adalah yang dikelola oleh pengusaha angkutan umum atau PO (Perusahaan Otobus) menengah ke bawah.

Faktor yang mengakibatkan masih banyaknya angkutan umum belum berbadan hukum adalah pengusaha angkutan umum dalam melakukan peralihan kendaraan angkutan umum yang masih dimiliki perorangan menjadi berbadan hukum yaitu tidak langsung mendaftarkan semua kendaraan angkutan umum yang dimiliki untuk diubah menjadi berbadan hukum. Namun pengusaha angkutan umum dalam melakukan peralihan angkutan umum pribadi menjadi berbadan hukum dilakukan secara bertahap.

Tabel 2 menunjukkan bahwa ketepatan sasaran pelaksanaan kebijakan angkutan umum berbadan hukum pada AKDP di Jawa Tengah adalah tidak efektif. Dikarenakan sebagian besar AKDP di Provinsi Jawa Tengah masih dimiliki 
perseorangan atau belum berbadan hukum. Besaran persentase yang diperoleh pada tahun 2015 hingga akhir bulan Juli 2017 kurang dari $60 \%$ yaitu tingkat pencapaian angkutan umum berbadan hukum pada AKDP di Jawa Tengah pada akhir bulan Juli sebesar $57 \%$ yaitu berjumlah 3690 kendaraan AKDP yang berbadan hukum.

Tabel 2. Realisasi AKDP Berbadan Hukum di Jawa Tengah Tahun 2015 - Juli 2017

\begin{tabular}{llccl}
\hline Tahun & $\begin{array}{c}\text { Target } \\
\text { (Unit) }\end{array}$ & $\begin{array}{c}\text { Realisasi } \\
\text { (Unit) }\end{array}$ & $\begin{array}{c}\text { Pencapaian } \\
(\%)\end{array}$ & Kriteria \\
\hline 2015 & 6501 & 1406 & $22 \%$ & $\begin{array}{l}\text { Tidak } \\
\text { Efektif }\end{array}$ \\
2016 & 6445 & 2758 & $43 \%$ & $\begin{array}{l}\text { Tidak } \\
\text { Efektif }\end{array}$ \\
& & & & Tidak \\
*Juli & 6445 & 3690 & $57 \%$ & Efektif \\
2017 & & & &
\end{tabular}

Sumber: Dinas Perhubungan Provinsi Jawa Tengah (diolah), 2017

Keberhasilan pelaksanaan kebijakan angkutan umum berbadan hukum didukung oleh kelancaran dalam proses pelaksanaan komunikasi antara pemerintah dengan pengusaha angkutan umum.

Dinas Perhubungan Provinsi Jawa Tengah dan DPD Organda Provinsi Jawa Tengah telah beberapa kali melakukan sosialisasi kepada pengusaha angkutan umum mengenai kebijakan angkutan umum berbadan hukum. Sosialisasi sudah dilakukan kepada koperasi dan PT yang bergerak di bidang usaha angkutan umum tiap kabupaten/kota di Jawa Tengah. Namun sosialisasi yang dilakukan belum maksimal dan belum semua kabupaten/kota di Jawa Tengah mendapatkan sosialisasi tersebut. Sosisalisasi yang sudah dilakukan yaitu di Kota Magelang, Kabupaten Magelang, Temanggung, Wonosobo, Brebes, Kota Tegal, Kabupaten Tegal, Pemalang, Kabupaten Pekalongan, dan Kota Pekalongan.

Sejauh ini sosisalisasi yang diberikan pemerintah kepada pengusaha angkutan umum mengenai kebijakan angkutan umum berbadan hukum telah dilakukan pada tiap kabupaten/kota di Jawa Tengah. Namun belum seluruhnya pengusaha AKDP di Jawa Tengah mendapatkan sosialisasi secara langsung tentang kebijakan angkutan umum berbadan hukum dan hanya mengetahui melalui internet serta pengusaha angkutan umum belum memahami tentang keuntungan yang akan diperoleh apabila berbadan hukum.

Pemerintah mengalami kesulitan apabila hendak memberikan bantuan kepada pengusaha angkutan umum dikarenakan syaratnya hanya angkutan umum berbadan hukum yang dapat menerima bantuan tersebut dan tidak dapat diberikan perseorangan. Tujuan kebijakan angkutan umum berbadan hukum yaitu agar pemerintah mudah dalam melakukan penertiban, pemantauan angkutan umum, serta pemberian subsidi dari pemerintah agar tidak salah sasaran yaitu subsidi berupa keringanan pajak dari pemerintah yang tidak dapat diberikan kepada perseorangan melainkan harus melalui badan hukum PT atau koperasi yang bergerak di bidang usaha angkutan umum agar pertanggung jawaban dan pendataannya jelas. Subsidi keringanan pajak yang dimaksud adalah berupa PKB dan BBNKB.

Pernyataan berbeda diungkapkan oleh pengusaha AKDP di Karanganyar, Kendal, Grobogan, Kudus, dan Jepara bahwa sudah diberikan subsidi kepada angkutan umum yang sudah berbadan hukum yaitu sebesar 70 persen. Namun besaran subsidi tersebut hanya dinikmati satu tahun saja dikarenakan adanya kebijakan Permendagri Nomor 28 Tahun 2017 bahwa subsidi yang diberikan pemerintah oleh pengusaha angkutan umum yang sudah berbadan hukum sebesar 40 persen jadi pengusaha angkutan umum orang harus membayar 60 persen dari total pajak yang harus dibayarkan.

Pengurangan besaran insentif pajak tersebut dikarenakan terbitnya Permendagri Nomor 28 Tahun 2017 yang berlaku mulai Juni 2017. Untuk menguatkan hasil penelitian peneliti membuktikan dengan membandingkan hasil wawancara dari DPD Organda Provinsi Jawa Tengah dan pengusaha AKDP pada Permendagri Nomor 28 Tahun 2017 diketahui 
bahwa dalam pasal 8 menjelaskan sebagai berikut :

Pengenaan PKB dan BBNKB untuk kendaraan bermotor angkutan umum orang ditetapkan sebesar $60 \%$ (enam puluh persen) dari dasar pengenaan $\mathrm{PKB}$ dan $\mathrm{BBNKB}$, pengenaan $\mathrm{PKB}$ dan $\mathrm{BBNKB}$ untuk kendaraan bermotor angkutan umum barang ditetapkan sebesar $80 \%$ (delapan puluh persen) dari dasar pengenaan $\mathrm{PKB}$ dan BBNKB.

Berdasarkan penjelasan di atas diketahui bahwa subsidi pajak yang diberikan kepada angkutan umum orang yang sudah berbadan hukum sebesar 40 persen sehingga untuk angkutan umum orang harus membayar sebesar 60 persen dari dasar pengenaan pajak yang ditetapkan. Hal tersebut tidak sesuai dengan Permendagri Nomor 101 Tahun 2017 bahwa subsidi $\mathrm{PKB}$ dan BBNKB untuk angkutan umum orang yang sudah berbadan hukum sebesar 70 persen dari dasar pajak yang ditetapkan.

Penertiban di lapangan mengenai kebijakan angkutan umum berbadan hukum dilakukan oleh Dinas Perhubungan Provinsi Jawa Tengah dibantu oleh pihak kepolisian dengan melakukan operasi gabungan di jalan atau razia di terminal. Sistemnya dengan pengecekan surat kelengkapan kendaraan seperti STNK (Surat Tanda Nomor Kendaraan), KP (Kartu Pengawasan), dll apabila surat-surat kelengkapan kendaraan angkutan umum tidak lengkap dan STNK masih atas nama pribadi atau belum berbadan hukum diberikan teguran dan himbauan untuk segera mengurus peralihan menjadi badan hukum dengan bergabung PT maupun koperasi yang sudah ada atau mendirikan badan hukum sendiri.

Dilakukan penertiban angkutan umum tujuannya untuk penertiban dokumen kendaraan bermotor angkutan umum terutama upaya peningkatan kesadaran masyarakat agar taat hukum dalam membayar pajak dan kewajiban berbadan hukum bagi kendaraan angkutan umum yang kepemilikannya masih dimiliki perorangan.

Namun Wakil Ketua DPD Organda Provinsi Jawa Tengah dan pengusaha AKDP menyatakan bahwa tidak adanya penertiban yang dilakukan oleh pemerintah kepada angkutan umum yang belum berbadan hukum dan hanya sekedar himbauan ataupun teguran untuk segera melakukan peralihan menjadi badan hukum serta penertiban di lapangan dilakukan pada saat razia di lapangan serta operasi di terminal dengan pengecekan suratsurat kelengkapan kendaraan angkutan umum.

Pengawasan yang dilakukan pemerintah mengenai kewajiban angkutan umum berbadan hukum hanya dilakukan pada saat pengusaha angkutan umum melakukan perpanjangan izin trayek dengan syarat kelengkapan STNK harus atas nama badan hukum. Apabila kepemilikan kendaraan angkutan umum masih berstatus pribadi atau belum berbadan hukum, Dinas Perhubungan hanya sekedar menghimbau kepada pengusaha angkutan umum agar secepatnya melakukan peralihan menjadi badan hukum karena apabila belum berbadan hukum SK izin trayek tidak dapat diterbitkan. Sedangkan pendapat berbeda diungkapkan oleh Wakil Ketua DPD Organda Provinsi Jawa Tengah bahwa pengawasan dilakukan melalui edukasi pada tiap DPC Organda kabupaten/kota di Jawa Tengah agar mensosialisasikan mengenai kebijakan angkutan umum berbadan hukum di wilayahnya masingmasing.

Pengusaha AKDP di Karanganyar, Kendal, Grobogan, Kudus, dan Jepara memberikan informasi yang berbeda-beda bahwa dalam proses pengawasan mengenai kebijakan angkutan umum berbadan hukum dilakukan dengan mengecek surat kelengkapan kendaraan angkutan umum pada saat razia di lapangan, pemerintah hanya melakukan pengawasan di lapangan mengenai peremajaan angkutan umum, kelayakan angkutan. Pengawasan juga dilakukan di lapangan pada saat pengusaha membayar pajak di samsat apabila belum berbadan hukum dihimbau oleh pihak kepolisian agar secepatnya mengurus badan hukum apabila ingin mendapatkan potongan pajak.

Sesuai dengan Peraturan Pemerintah Nomor 74 Tahun 2014 tentang Angkutan Jalan bahwa pengawasan angkutan orang dengan kendaraan bermotor umum dilakukan di 
terminal, tempat wisata, ruas jalan, dan tempat keberangkatan angkutan.

Keberhasilan kebijakan angkutan umum berbadan hukum tidak terlepas dari faktor-faktor yang mempengaruhinya. Hal tersebut dapat diketahui dari bagaimana pelaksanaan kebijakan angkutan umum berbadan hukum pada AKDP di beberapa kabupaten di Jawa Tengah dengan diketahui faktor-faktor yang mempengaruhi dalam pelaksanaan kebijakan angkutan umum berbadan hukum.

Keuntungan yang diperoleh pengusaha angkutan umum apabila angkutan umum yang dimiliki berbadan hukum adalah diberikannya subsidi keringanan pajak berupa $\mathrm{PKB}$ dan BBNKB dari pemerintah sebesar 70 persen untuk angkutan umum orang. Jadi pengusaha angkutan umum orang hanya membayar 30 persen dari total pajak yang seharusnya dibayarkan serta badan hukum tersebut juga bertujuan untuk meningkatkan standar pelayanan dan pengelolaan angkutan umum di Provinsi Jawa Tengah agar lebih terorganisasi dengan baik.

Namun berbeda halnya dengan yang diungkapkan oleh Wakil Ketua DPD Organda Provinsi Jawa Tengah mengenai keuntungan yang diperoleh apabila pengusaha angkutan umum berbadan hukum yaitu mendapatkan subsidi pajak dari pemerintah yang awalnya dikenakan hanya 30 persen untuk angkutan umum orang, namun kini pengusaha harus membayar 60 persen dari dasar pengenaan pajak yang ditetapkan. Mengenai alasan pengurangan besaran subsidi pajak yang diterima pengusaha angkutan umum yang berbadan hukum belum mengetahui secara pasti penyebab pengurangan subsidi yang diberikan pemerintah kepada angkutan umum yang berbadan hukum.

Dengan adanya pengurangan subsidi tersebut pengusaha angkutan umum merasa dirugikan karena keuntungan yang didapatkan setelah berbadan hukum tidak sesuai dengan kebijakan awal mengenai subsidi yang diberikan untuk angkutan umum orang apabila berbadan hukum yaitu sebesar 70 persen tetapi sekarang hanya 40 persen. Tentunya hal tersebut tidak mampu menutupi biaya yang telah dikeluarkan pengusaha angkutan umum untuk melakukan peralihan menjadi badan hukum atau mendirikan badan hukum sendiri.

Selama ini pengusaha angkutan umum mempunyai banyak beban yang harus ditanggung dalam menjalankan usahanya di bidang transportasi umum diantaranya yaitu dengan membayar retribusi, pengurusan izin trayek, peremajaan kendaraan angkutan umum, dll. Adanya pengurangan pajak untuk angkutan umum yang berbadan hukum diharapkan dapat mengurangi beban pengusaha angkutan umum khususnya pada AKDP.

Untuk itu diharapkan semua pengusaha angkutan umum antar kota dalam provinsi di Jawa Tengah agar segera melakukan peralihan kendaraan angkutan umum yang masih berstatus pribadi agar diubah menjadi berbadan hukum PT atau koperasi yang bergerak di bidang usaha angkutan umum.

Namun kenyataannya menurut pengusaha AKDP di Karanganyar, Kendal, Grobogan, Kudus, dan Jepara bantuan subsidi pajak yang diberikan pemerintah kepada pengusaha angkutan umum yang berbadan hukum belum merasakan dampak yang diterima dari keuntungan setelah melakukan peralihan kendaraan angkutan umum pribadi menjadi berbadan hukum dikarenakan besaran subsidi pajak yang diberikan belum mampu menutup biaya yang telah dikeluarkan dalam proses peralihan menjadi berbadan hukum serta untuk mendirikan PT membutuhkan biaya operasional yang tinggi.

Surat-surat kepemilikan kendaraan diubah menjadi atas nama badan hukum, Penerapan kebijakan angkutan umum berbadan hukum di Provinsi Jawa Tengah menuai berbagai tanggapan dari pengusaha AKDP di beberapa kabupaten di Jawa Tengah mengenai konsekuensi yang diterima pengusaha angkutan umum apabila bergabung dengan badan hukum yang sudah ada yaitu surat-surat kepemilikan kendaraan angkutan umum diubah menjadi atas nama badan hukum tersebut dan bukan atas nama perorangan. Namun apabila pengusaha angkutan umum mendirikan badan hukum sendiri kepemilikan kendaraan angkutan umum 
tetap atas nama badan hukum tetapi termasuk usaha yang dikelola sendiri.

Menanggapi hal tersebut pengusaha AKDP di Karanganyar, Kendal, Grobogan, Kudus, dan Jepara menyatakan bahwa syarat dalam peralihan kendaraan angkutan umum yang masih dimiliki perseorangan menjadi badan hukum terlalu banyak dan biaya operasional yang dikeluaran untuk peralihan menjadi badan hukum tinggi. Sedangkan pengusaha AKDP yang belum berbadan hukum keberatan untuk melakukan peralihan menjadi berbadan hukum dikarenakan konsekuensi apabila berbadan hukum maka status kepemilikan angkutan umum di STNK diubah menjadi atas nama badan hukum tersebut dan bukan perseorangan lagi.

Wakil Ketua DPD Organda Provinsi Jawa Tengah mengaku bahwa adanya keluhan dari pengusaha angkutan umum apabila angkutan umum mereka diubah menjadi berbadan hukum yaitu dokumen BPKB dan STNK akan diubah menjadi atas nama perusahaan atau badan hukum tersebut dan bukan atas nama perseorangan lagi padahal modal awal berasal dari pengusaha angkutan umum sendiri.

Biaya operasional tinggi, kecukupan biaya pengusaha angkutan umum dalam proses peralihan kendaraan angkutan umum yang masih dimiliki perseorangan menjadi berbadan hukum merupakan salah satu faktor penyebab masih banyak kepemilikan angkutan umum jenis AKDP di beberapa kabupaten di Jawa Tengahyang belum berbadan hukum. Pengusaha angkutan umum dengan kondisi ekonomi menengah tidak mampu mengikuti pelaksanaan program kebijakan angkutan umum berbadan hukum karena dalam peralihan menjadi badan hukum membutuhkan biaya operasional yang tinggi.Hal tersebut dinilai memberatkan bagi pengusaha angkutan umum terutama untuk pengusaha AKDP yang memiliki pendapatan usaha yang rendah artinya mereka hanya memiliki beberapa kendaraan angkutan umum antar kota dalam provinsi.

Biaya untuk mendirikan badan hukum sangat tinggi dan belum mampu menutup modal yang telah dikeluarkan untuk mendirikan badan hukum tersebut dengan bantuan yang diterima pengusaha dari pemerintah, sehingga dalam melakukan peralihan menjadi badan hukum pengusaha angkutan umum melakukan peralihan menjadi baerbadan hukum sistemnya secara bertahap dan tidak langsung semua diubah menjadi atas nama badan hukum

Tidak diterapkannya sanksi tegas dari pemerintah, suatu program kebijakan tentunya harus ditaati dan dilaksanakan oleh subjek kebijakan dalam hal ini adalah pengusaha angkutan umum antar kota dalam provinsi di Jawa Tengah. Sewajarnya apabila melanggar program yang telah diperintahkan di dalam kebijakan tersebut akan mendapatkan sanksi dari pemerintah. Namun kenyataannya dalam pelaksanaan kebijakan angkutan umum berbadan hukum di Jawa Tengah pengusaha AKDP yang belum berbadan hukum masih menjalankan usahanya dan beroperasi tanpa mendapatkan sanksi tegas dari pemerintah.

Berbeda halnya yang diungkapkan oleh Dinas Perhubungan Provinsi Jawa Tengah dan Wakil Ketua DPD Organda Provinsi Jawa Tengah bahwa sanksi yang diberikan kepada pengusaha angkutan umum yang belum berbadan hukum adalah kartu pengawasan tidak dapat diterbitkan karena status kendaraan masih dimiliki perseorangan atau belum berbadan hukum dan selanjutnya tidak dapat melakukan perpanjangan izin trayek. Hal yang sama diungkapkan bahwa selebihnya hanya teguran dan himbauan kepada pengusaha AKDP yang belum berbadan hukum untuk segera melakukan peralihan kendaraan angkutan umum yang masih berstatus perorangan untuk segera beralih menjadi badan hukum.

Hal tersebut bertentangan dengan UU No 22 Tahun 2009 bahwa setiap kendaraan yang belum didaftarkan atau diregistrasi tidak boleh beroperasi dan harus atas nama badan hukum. Registrasi dibuktikan dengan diterbitkannya Buku Pemilik Kendaraan Bermotor (BPKB), penerbitan Surat Tanda Nomor Kendaraan Bermotor (STNK), dan Tanda Nomor Kendaraan Bermotor (TNKB).

Subsidi pajak dikurangi, keuntungan yang diperoleh pengusaha apabila angkutan umum mereka berbadan hukum adalah diberikannya 
subsidi pajak dari pemerintah berupa PKB dan BBNKB sebesar 70 persen untuk angkutan umum orang. Jadi pengusaha angkutan umum orang hanya membayar sebesar 30 persen dari dasar pengenaan pajak yang ditetapkan. Namun pengusaha AKDP yang sudah berbadan hukum merasa dirugikan akibat subsidi pajak yang sekarang diterima dipangkas dikarenakan terbitnya Permendagri Nomor 28 Tahun 2017. Sehubungan dengan telah ditetapkannya Permendagri No 28 Tahun 2017 tentang Penghitungan Dasar Pengenaan Pajak Kendaraan Bermotor dan Bea Balik Nama Kendaraan Bermotor Tahun 2017 bahwa peraturan tersebut diberlakukan mulai bulan 7 Juni 2017.

Dalam PermendagriNo 28 Tahun 2017 terdapat perubahan pada besaran pengenaan PKB dan BBNKB untuk angkutan umum berbadan hukum. Pengenaan pajak untuk angkutan umum orang yang sudah berbadan hukum dasar yang semula dikenakan 30 persen kini naik menjadi 60 persen.

Menanggapi mengenai pengurangan subsidi yang diterima pengusaha angkutan umum yang sudah berbadan hukum, pengusaha AKDP di beberapa kabupaten di Jawa Tengah mengungkapkan bahwa tidak ada sosialisasi terkait pengurangan subsidi pajak yang diterima untuk angkutan umum yang berbadan hukum. Pengusaha angkutan umum merasa dirugikan karena subsidi tersebut belum mampu menutupi biaya yang telah dikeluarkan untuk mendirikan Perseroan Terbatas ataupun dalam proses peralihan menjadi berbadan hukum yang mengeluarkan biaya besar.

Untuk pembuktian apakah benar bahwa subsidi yang diterima pengusaha angkutan umum orang yang sudah berbadan hukum sebesar 40 persen sehingga pengusaha angkutan umum orang harus membayar sebesar 60 persen dari dasar pengenaan pajak yang ditetapkan, penulis memeriksa dengan dokumen kebijakan pada Peraturan Menteri Dalam Negeri Nomor 28 Tahun 2017 tentang Penghitungan Dasar Pengenaan Pajak Kendaraan Bermotor Dan Bea Balik Nama Kendaraan Bermotor Tahun 2017 bahwa diketahui pada pasal 8 sebagai berikut :
Pengenaan PKB untuk Kendaraan Bermotor Angkutan Umum orang ditetapkan sebesar $60 \%$ (enam puluh persen) dari dasar pengenaan $\mathrm{PKB}$, pengenaan BBNKB untuk Kendaraan Bermotor Angkutan Umum orang ditetapkan sebesar $60 \%$ (enam puluh persen) dari dasar pengenaan BBNKB, pengenaan $\mathrm{PKB}$ untuk Kendaraan Bermotor Angkutan Umum barang ditetapkan sebesar $80 \%$ (delapan puluh persen) dari dasar pengenaan $\mathrm{PKB}$, pengenaan BBNKB untuk Kendaraan Bermotor Angkutan Umum Barang ditetapkan sebesar 80\% (delapan puluh persen) dari dasar pengenaan BBNKB.

\section{SIMPULAN}

Berdasarkan hasil penelitian dan pembahasan penelitian diambil kesimpulan bahwa efektivitas kebijakan angkutan umum berbadan hukum pada AKDP di beberapa kabupaten di Jawa Tengah belum tercapai. Terbukti dari belum tercapainya target pelaksanaan kebijakan angkutan umum berbadan hukum pada AKDP di Jawa Tengah yaitu hanya 57 persen AKDP yang sudah berbadan hukum, dengan kata lain masih banyak kepemilikan kendaraan AKDP di Jawa Tengah yang dimiliki perorangan atau belum berbadan hukum. Dari pengukuran sosialisasi program sudah dilaksanakan dengan baik meskipun belum semua pengusaha angkutan umum dan koperasi yang bergerak di bidang usaha angkutan umum mendapatkan sosialisasi terkait kebijakan angkutan umum berbadan hukum. Akan tetapi apabila dilihat dari indikator hasil yang lainnya, seperti tujuan program dan pemantauan program dalam pelaksanaan kebijakan angkutan umum berbadan hukum pada AKDP di beberapa kabupaten di Jawa Tengah belum maksimal. Adapun faktor-faktor yang mempengaruhi dalam pelaksanaan kebijakan angkutan umum berbadan hukum pada AKDP di beberapa kabupaten di Jawa Tengah yaitu : faktor pendorong pelaksanaan kebijakan angkutan umum berbadan hukum pada AKDP di Karanganyar, Kendal, Grobogan, Kudus, dan Jepara yaitu pengusaha angkutan umum mendapatkan insentif pajak berupa PKB dan 
BBNKB apabila status kepemilikan angkutan umum berbadan hukum serta dapat menekan biaya operasional angkutan umum, faktor penghambat pelaksanaan kebijakan angkutan umum berbadan hukum pada AKDP di Karanganyar, Kendal, Grobogan, Kudus, dan Jepara yaitu : Pengusaha angkutan umum keberatan apabila status kepemilikan dalam surat-surat kendaraan angkutan umum diubah menjadi atas nama badan hukum PT atau koperasi, biaya operasional untuk proses peralihan menjadi badan hukum tinggi, tidak diterapkannya sanksi tegas dari pemerintah kepada pengusaha angkutan umum yang belum berbadan hukum, pengurangan subsidi pajak yang diterima pengusaha angkutan umum yang sudah berbadan hukum akibat adanya Permendagri Nomor 28 Tahun 2017.

\section{DAFTAR PUSTAKA}

Budiani, Ni Wayan. (2007). Efektivitas Program Penanggulangan Pengangguran Karang Taruna "Eka Taruna Bhakti" Desa Sumerta Kelod Kecamatan Denpasar Timur Kota Denpasar. Jurnal Ekonomi dan Sosial INPUT. Vol 02 No. 1. Hal 53.

Keputusan Menteri Dalam Negeri Nomor 690.900.327 Tahun 1996 tentang Pedoman Penilaian dan Kinerja Keuangan.
Peraturan Gubernur Jawa Tengah Nomor 23 Tahun 2015 tentang Penghitungan Dasar Pengenaan Pajak Kendaraan Bermotor Dan Bea Balik Nama Kendaraan Bermotor Untuk Kendaraan Bermotor Pembuatan Sebelum Tahun 2015.

Peraturan Menteri Dalam Negeri Republik IndonesiaNomor 101 Tahun 2014 tentangPenghitunganDasarPengenaanPajakK endaraanBermotor Dan Bea BalikNamaKendaraanBermotorTahun 2015.

Peraturan Menteri Dalam Negeri Republik IndonesiaNomor72Tahun

2016tentangPerubahan Atas Peraturan Menteri Dalam Negeri Nomor 12 Tahun 2016 Tentang Penghitungan Dasar Pengenaan Pajak Kendaraan Bermotor Dan Bea Balik Nama Kendaraan Bermotor Tahun 2016.

Peraturan Pemerintah Nomor 74 Tahun 2014 tentang Angkutan Jalan.

Sugiyono. (2016). Metode Penelitian Kuantitatif, Kualitatif, dan $R \& D$. Bandung: Alfabeta.

Suseno, Deky A. (2013). Efektivitas Dan Kemandirian Keuangan Daerah Provinsi Jawa Tengah Pasca Diterapkannya Desentralisasi Fiskal. Economics Development Analysis Journal, Vol 02 No. 2. Hal 1-8.

Undang-Undang Nomor 22 Tahun 2009 tentang Lalu Lintas dan Angkutan Jalan.

http://tangselpos.co.id/2016/02/05/angkutanumum-wajib-berbadan-hukum/.(Diakses pada $\quad 30 \quad$ Desember 2017). 